DOI 10.17150/978-5-7253-3001-4.28

В. А. ШІ АЛ АМОВ

УДК 614(571.53)(091)

ББК 65.9(2P54)441г

\title{
АССЕНИЗАЦИОННОЕ ДЕЛО \\ В ВОСТОЧНОЙ СИБИРИ В 1920-е ГОДЫ
}

В статье рассматривается санитарное состояние городов Восточной Сибири в 1920-е гг. и попытки решения проблемы утилизации отходов. Особое внимание обращено на организацию ассенизационных обозов и полей.

Ключевые слова: история здравоохранения, история медицины, санитарное дело, Восточная Сибирь, ассенизационный обоз, ассенизационные поля. 


\section{SEWAGE DISPOSAL IN EASTERN SIBERIA IN THE 1920s}

The article discusses the sanitary condition of cities in Eastern Siberia in the 1920s. and attempts to solve the problem of waste disposal. Special attention is paid to the organization of cesspool carts and fields.

Keywords: history of public health, history of medicine, sanitary business, Eastern Siberia, cesspool transportation, cesspool fields

Годы Гражданской войны запомнились населению Восточной Сибири не только ужасами войны, но и масштабной эпидемией тифозных заболеваний. К тифу прибавилась холера, наступавшая одновременно с западной Сибири и из Маньчжурии. Колчаковская администрация худо или бедно сдерживала эпидемические волны [15, с. 232-249]. Сильнейшим ударом оказалось движение в зиму 1919-1920 гг. войск генерала В.О. Каппеля через всю Восточную Сибирь. До Забайкалья добралось около 25 тыс. чел., треть из которых была больна «сыпняком», почти все в пути перенесли три фоомы тифа. По пути они инфицировали население, после их прохода волна эпидемий захлестнула Восточную Сибирь. Следовавшая за ней 5-я красная армия только усугубила ситуацию, предоставив болезни свежий горючий материал [2, с. 198]. Самым страшным было то, что тиф был занесен в сельскую местность, что раньше удавалось сдерживать. Из-за слабого санитарного оборудования и отсутствия медперсонала, отсутствия у населения элементарных гигиенических навыков тиф продержался в Восточной Сибири все 1920-е гг.

К сожалению, мы не располагаем конкретными цифровыми данными о масштабах бедствия в 1920 г. из-за отсутствия точного учета противоборствующих сторон. Имеются лишь отрывочные данные, которые отчасти проливают свет на интересующий нас вопрос. Например, в Чите за 1919 г. было зафиксировано по неполным данным 669 больных «сыпняком», что составляет 11,1 чел. на 10 тыс. чел. населения города, а это в 11 раз больше довоенных показателей. За полгода 1920 г. переболело еще 536 чел. [11, с. 400]. Следовательно, реальные цифры более высокие. По Иркутску неоднократно пытались отыскать сведения об уровне заболеваемости, но их так и не нашли. А.Ф. Секулович утверждает, что сыпным и возвратным тифами в этот год переболело 11634 чел., брюшным тифом - 3 436, дизентерией - 2847 , дифтеритом - 2 190, скарлатиной - 332 и оспой - 551 [16, с. 61]. Однако и здесь данные явно неполные: для города заболеваемость велика, а для губернии явно низкая, что не вяжется с другими свидетельствами. Вероятно, она использовала данные по Иркутску, может 
быть с присоединением некоторых регионов губернии. В общем, на сегодняшний день мы не располагаем надежными источниками о масштабах катастрофы.

Одним из главнейших источников распространения тифа является скученность и антисанитария. В период колчаковской власти городские администрации едва справлялись с очисткой городского пространства. Привычные методы уже не работали. Постепенно отходы накапливались. А теперь представим на минуту, кокой поток людей и лошадей прошел через всю Восточную Сибирь в 1920 г. Железная дорога с запада вплоть до Ачинска была заставлена железнодорожными составами, где погибло немало людей, которых никто не хоронил. В лагере для военнопленных под Красноярском по словам Р.М. Азарх одна из казарм была отведена под трупы умерших от тифа [1, с. 100]. В самом городе были сосредоточены все резервы адмирала Колчака. Огромное количество лошадей. По мере следования вдоль Транссиба корпус ген. Каппеля занимал города и станции, а следом за ним проходила 5-я Красная Армия. При этом все движение осуществлялось на лошадях. То же самое повторилось в пос. Иннокентьевском. В городе оказалось сосредоточены войска Политцентра, произошли бои. Кроме того, многочисленные контингенты военнослужащих, беженцев и лошадей прошли через Верхнеудинск, Читу, Троицкосавск, Нерчинск. Воинские команды в Гражданскую войну уже были лишены дисциплинированности царской армии. Их практически невозможно было заставить производить очистку города от конского навоза, отходов забоя скота, мусора. Практически каждый городской двор оказывался в антисанитарном состоянии. Для примера используем докладную записку городского головы г. Читы начальнику читинского гарнизона от 15 июня 1920 г.: «В городской управе имеется несколько протоколов и донесений, свидетельствующих произвольную свалку солдатами нечистот, навозу и мусора не на отведенном для того городом свалочном месте, а в ближайших окрестностях Читы: в лесу за Ново-Бульварной улицей, около Архиерейской заимки, в пределах р. Кайдаловки и в других местах... Также неоднократно управа сообщала о вывозе солдатами в ближайшие окрестности города трупов павших животных, хотя для свалки трупов отведено также особое место с вырытыми на нем ямами... начальником гарнизона был издан приказ об очистке обывательских квартир и дворов силами и средствами расквартированных в них воинских частей. Приказ этот, к сожалению, не имел успеха... Наконец, на последнее время положение с очисткой осложнилось еще реквизицией у подрядчика 9 лошадей...» [3, л. 128-129 об.].

На Восточном фронте Красной армии еще весной 1919 г. было выделено санитарное управление (санупр) во главе с М.И. Барсуковым. В ближайшем тылу армий образовывались эвакуационные пункты, 
а в ближайшем крупном городе или станции головной эвакуационный пункт. По мере продвижения 5-й советской армии по Сибири медицинские учреждения переходили в ведение здравотдела Сибревкома $[14$, c. $33-36]$.

Поскольку на местах в разгар эпидемии здравотделы только начали формироваться и сами толком не знали принципы советского здравоохранения, то было решено прибегнуть к созданию чрезвычайных органов по борьбе с тифом (чекатиф), основные положения о котором были оговорены в декретах СНК 28 января и 10 апреля 1919 г. В Красноярске, Иркутске, а позднее в Якутске и Верхнеудинске образуются так называемые «пятерки» - коллегиальный орган, принимающий основные решения. Обычно его возглавлял врач, иногда председатель местного ревкома. В качестве членов выступали представители ведомств: собеса, санупра 5-й армии (санупр-5), путей сообщения, ревкома. Таким образом, чекатиф был органом, оптимизирующим работу различных инстанций [17, с. 202-205]. В Иркутске чекатифом руководил известный врач, революционер Ф.Н. Петров, вскоре возглавивший министерство здравоохранения ДВР. В Красноярске главой чекатифа стал В.Ф. Дружицкий, одновременно возглавлявший губернский отдел образования. В Якутске председателями чекатифа в разное время были Н.Г. Юдин, И.Н. Скрябин, И. Колмогоров [7, л. 1; 9, л. 28 об.; 12, с. 2]. На местах возникали уездные, городские и волостные чекатифы.

Главных задач у чекатифа было две: изоляция и очистка. Для осуществления изоляции в крупных городах санупр-5 образует тыловой эвакуационный пункт (Ачинск, Красноярск, Иркутск, Верхнеудинск, Петровск-Забайкальский, Чита). Любой транспорт подлежал проверке на изопропункте, а в случае необходимости - санобработке. Всех подозрительных по заболеванию лиц изолировали, пропускали через баню и вошебойку. В каждом районе городов Восточной Сибири организовывались санкомиссии (тройки), которые периодически делали подворный обход. Там, где выявлялись заболевания, вывешивался черный фрлаг и накладывался карантин, который, впрочем, довольно часто нарушался. Дело доходило до судов. Чекатиф брал под свой контроль запасы дезосредств (мыло, карболовая кислота, сера, известь, деготь). Также чекатифр имел право реквизировать любое здание для изоляции больных. Города стремились разгрузить, воинские части выводили в сельские местности, на курорты, для беженцев организовали реэвакуационную комиссию, с помощью международного Красного Креста (представитель миссии доктор Жорж Монтандон) создали комиссию по репатриации военнопленных Первой мировой войны, вывозившихся через линию фронта во Владивосток [10, с. 2].

После установления советской власти в регионе нужно было взяться за очистку городов. Наиболее нетерпимые загрязненные участки го- 
родов, военные части и учреждения очищали специально созданные отряды из свободных обозных военно-санитарного транспорта и выздоравливающих солдат [9, л. 28 об.]. Очистка всего остального городского пространства возлагалось на коммунальные хозяйства. Однако положение в них оказалось не из лучших. В качестве примера приведем доклад заведующего комхозом Красноярска заместителю председателя Сибревкома В.Н. Соколову от 16 июня 1920 г.: «К моменту восстановления советской власти город был совершенно перегружен, масса нечистот, обоза почти никакого: ни кони, ни люди никуда не годились. В настоящее время в ассенизационном обозе 53 лошади, годных из них не более 25 , бочек 20, коробов 12. Лошадей прикупить было бы еще быть может и возможно, но достать телег и бочек нет надежды ни малейшей; снабдить рабочих одеждой не могли ниоткуда, поэтому и рабочих в ассенизационный обоз найти почти не возможно...» [8, л. 12].

Естественно, что такие обозы без посторонней помощи не могли решить задачу по очистке «авгиевых конюшен». Для этого по всей Сибири прошли мероприятия под названием «неделя чистоты», на которые мобилизовали все население городов. Так, по данным Р.М. Азарх из Красноярска было вывезено 65 тыс. возов нечистот [1, с. 128]. Многие города впервые после 1914 г. вычистились от навоза и мусора. Производилась уборка павших животных. Были введены правила, запрещающие хоронить людей в центре городов. Установились места свалок и порядок вывоза отходов.

Все меры по очистке крупных населенных пунктов Восточной Сибири дали хорошие результаты. Накал эпидемий к концу апреля 1920 г. удалось сбить. Вследствие этого губернские чекатифы были закрыты. В 1921 и 1922 гг. эпидемии повторялись. С ними боролись теми же мерами. С окончанием Гражданской войны и переходом к Нэпу, изопропункты были закрыты также, как и головные эвакуационные пункты. и постепенно переданы гражданским властям. С этого момента ассенизационные обозы оказались сильно сокращены и переведены на рыночные рельсы.

Несмотря на спад инфекционных заболеваний, их угроза все 1920-е гг. висела над городами, как «дамоклов меч». Каждый город Восточной Сибири имел свою особенность, часто определяемую климатом и окружающим рельефом. Большинство городов располагалось по берегам крупных рек - Енисей, Ангара, Лена, Селенга, Ингода, которые стабильно снабжали население питьевой водой и одновременно способствовали очищению прибрежной территории во время половодья. Часть городов располагалось внизу возвышенностей, с которых весной наблюдались сильные потоки талой воды, которые по пути вбирали в себя городской мусор и навоз, загрязнявшие водоемы. Весной и осень горожанам приходилось потреблять воду негигиеничного вида. Данный 
фактор часто наблюдался в Якутске, Олекминске, Енисейске, Минусинске. Засушливый климат, частые ветры и песчаная почва в Чите создавали ее колорит. С одной стороны, ветры выдували из города часть нечистот, влага легко просачивалась в почву, не образуя застойных луж. В то же время тучи песка служили переносчиками инфекционных заболеваний. Такие же проблемы были в Троицкосавске, Верхнеудинске и др. В большинстве городов Восточной Сибири протекали небольшие речушки и ручьи, сильно загрязняемые населением, что создавало постоянный очаг инфекций. Таковы, например, Кача в Красноярске, Чулым в Ачинске, Ушаковка в Иркутске, Уда в Верхнеудинске. Большинство городских поселений Восточной Сибири располагалась по железнодорожным путям, что способствовало их бурному развитию. Однако большие потоки людей способствовали быстрому распространению инфекционных заболеваний, что требовало дополнительной санитарной защиты. Промышленные предприятия (часть Кузбасса, Черембасс, Минусинзолото, Бодайбо, Усольский солеваренный завод и др.) до революции вообще были лишены ассенизационных служб.

Канализация в Восточной Сибири отсутствовала. При бараках, общежитиях и домах-коммунах, правительственных и общественных учреждениях имелись общественные туалеты и выгребные ямы. В частных усадьбах устраивались туалеты и выгребные ямы самых разнообразных устройств. По мере наполнения эти санитарные приспособления требовали очистки и дезинфекции. Обилие скота и особенно лошадей, сильно загрязняло дворы и улицы городов. Власти требовали от владельцев очистки территории, временами штрафовали. Обычно шумиха появлялась весной и продолжалась до июня месяца, после чего накал страстей несколько снижался. Чтобы урегулировать вывоз бытовых отходов, коммунотдел большинства городов содержал ассенизационный обоз (в Иркутске на 60 бочек, в Красноярске на 30 бочек, в Чите на 45 бочек, в Киренске на 1 бочку). Иногда создавались обозы мест лишения свободы, обслуживавшие и город (в Красноярске на 18 бочек, в Чите на 15 бочек) [4, л. 125; 5, л. 31; 6, л. 20]. Частники также не брезговали этим промыслом, например, крестьяне в зимнее время или китайцы, особенно в Забайкалье. Так в Иркутске частники превосходили городской обоз в 2,5 раза, а в Красноярске в 5 раз. Мелкие города либо на договорной основе привлекали частников, либо вообще бездействовали (Нижнеудинск, Черемхово, Троицкосавск, все города Якутии). Обозы обязаны были вывозить отходы в ночное время, чтобы минимизировать контакты с населением. В промышленных районах отходы часто сбрасывали в отработанные шахты или в водоемы, сильно загрязняя их.

Большинство городов отводило под бытовые отходы специальные свалочные места, намеченные санитарными комиссиями. За отвала- 
ми в виде продольных канав следили специальные сторожа. Как правило, места свалок были удалены от города на расстояние не менее 1 км, что толкало нерадивых ассенизаторов и жителей города сваливать свой «груз» в первом попавшемся удобном месте. В итоге берега рек, пустыри, рытвины и канавы, лужи и озера, заброшенные дворы превращались в стихийные свалки. По расчетам санитарных врачей Красноярска и Иркутска ассенизационные обозы вывозили только 10 \% бытовых отходов. Эти города остро нуждались в канализации. В качестве паллиативных мер они прибегли к ассенизационным полям, менее загрязнявшим пространство, к тому же позволявшим выращивать различные сельскохозяйственные культуры. Прочие города не имели и этого. Впрочем, Восточная Сибирь в этом плане была на уровне большинства городов Советской России (в 1926 г. только в 16 из 250 городов имелась канализация, охватывавшая от 1,6 до 50 \% домовладений) [13, с. 65; 18, с. 28-30; 19, с. 6-12].

Конечно, такие полумеры не могли спасти города от сильно загрязнения. Требовались более решительные меры. Таким крупным городам как Иркутск и Красноярск явно требовалась канализация, но обойтись собственными средствами без помощи государства даже они не могли. Так что эта задача досталась по наследству следующему поколению городских исполкомов.

\section{Список использованной литературы и источников}

1. Азарх Р. М. У великих истоков / Р. М. Азарх. - М. : Воениздат, 1967. $160 \mathrm{c}$.

2. Великий Сибирский Ледяной поход / под ред. С. В. Волкова. - М .: ЗАО Центрополиграф, 2004. - 718 с.

3. Государственный архив Забайкальского края (ГАЗК). - Ф. 1 вр. - Оп. 2. Д. 846.

4. ГАЗК. - Ф. р-623. - Оп. 1. - Д. 13.

5. Государственный архив Иркутской области. - Ф. p-1114. - Оп. 1. - Д. 24.

6. Государственный архив Красноярского края (ГАКК). - Ф. p-319. Оп. 1. - Д. 33.

7. ГАКК. - Ф. р-993. - Оп. 1. - Д. 60.

8. Государственный архив Новосибирской области (ГАНО). - Ф. p-1. Оп. 1. - Д. 186.

9. ГАНО. - Ф. р-1. - Оп. 1. - Д. 375.

10. Дальне-Восточная республика (Верхнеудинск). - 1920. - 16 сент.

11. Ишерский В. Первая сыпнотифозная эпидемия в Чите и сопровождающего ее возвратного тифа / В. Ишерский // Медицинский журнал Забайкальского общества врачей. - 1923. - № 5. - С. 399-410.

12. Ленский коммунар (Якутск). - 1921. - 4 дек.

13. О деятельности санитарно-профилактического подотдела Красноярского окрздрава за 1925 год // Сибирский медицинский журнал. - 1926. № 4. - C. 65-66. 
14. Рипп Г. Х. Советская военная медицина во время гражданской войны и интервенции в Сибири (1918-1922 гг.) / Г. Х. Рипп. - Новосибирск : Изд-во «Советский воин», 1987. - 188 с.

15. Рынков В. М. Санитарно-медицинские службы на Востоке России в антибольшевистский период Гражданской войны (вторая половина 1918-1919 гг.) / В. М. Рынков // Чтения памяти профессора Е. П. Сычевского : сб. докл. / отв. ред. А. И. Донченко. - Благовещенск : Изд-во БГПУ, 2007. - Вып. 7. - С. 232-249.

16. Секулович А. Ф. Из истории борьбы с заразными болезнями в Иркутской области : очерки / А. Ф. Секулович. - Иркутск : Изд-во ИГУ, 1994. - 240 с.

17. Становление и развитие здравоохранения в первые годы советской власти (1917-1924 гг.) : сб. док. / ред. кол. М. И. Барсуков, А. С. Дремов, А. П. Куропатов. - М. : Изд-во «Медицина», 1966. - 544 с.

18. Шварцман М. И. К вопросу об организации ассенизационных, агрикультурных полей в г. Иркутске / М. И. Шварцман // Сибирский медицинский журнал. - 1929. - № 4. - С. 28-30.

19. Шварцман М. И. Санитарное состояние города Иркутска / М. И. Шварцман // Сибирский медицинский журнал. - 1930. - № 4. - С. 6-12.

\section{Информация об авторе}

Шаламов Владимир Александрович - кандидат исторических наук, доцент, кафедра истории России, Иркутский государственный университет, 664025, г. Иркутск, ул. Чкалова, 2; e-mail: Wladimir13х@уа.ru

\section{Author}

Vladimir A. Shalamov - PhD in History, Associate Professor Department of History of Russia, Irkutsk State University, 2 Chkalov St., 664025, Irkutsk, Russia; e-mail: Wladimir13x@ya.ru 